\title{
THE CONSTITUENT MINERALS OF SOME SOILS OF PUERTO RICO
}

\author{
C. D. Jeffries, J. A. Bonnet, and F. Abruña ${ }^{1}$ \\ INTRODUCTION
}

The constituent minerals of soils are the mineral groups which make up the bulk of the inorganic portion. These inorganic materials make up approximately 95 percent of soils in general and contribute materially to their properties. The importance of these minerals has been emphasized $(9)^{2}$ for some time in a general way, but data on most soils, and particularly, on tropical soils are lacking.

The constituent minerals in soils are feldspar, quartz, mica, and claymineral groups. The properties of these minerals vary considerably within a group or series. In studying the minerals of soils, it is of importance to determine the type of mineral of the particular group or series being investigated, that is to say, what kind of feldspar, clay mineral, etc., occurs in any particular soil.

The variability of the soils of Puerto Rico has been discussed by Bonnet (4), Roberts (13), Thorp (14), and others, but a complete mineral study for only one soil, Catalina clay, has been reported by Bonnet (3).

\section{COLLECTION OF SOIL AND ROCK SAMPLES}

Studies on the mineral characteristics and mode of formation of tropical soils were initiated, in February 1943, at the former Institute of Tropical Agriculture at Mayaguez, P. R., by Bonnet, the first junior author, then Assistant Director and Chief Soils Technologist, of the Institute. In September 1944, the studies were continued by Bonnet in the Soils Department of the Agricultural Experiment Station of the University of Puerto Rico at Río Piedras, under a cooperative agreement with the Institute. Dr. Jeffries visited the Institute for a 2-month period in 1943 and helped in the collection of the soil and rock samples throughout the Island of Puerto Rico and in the organization of the laboratory work carried later at the Experiment Station. The soils ${ }^{3}$ were prepared for analysis at Río Piedras, and the sand, silt, and clay fractions together with the

${ }^{1}$ Professor of Soil Technology, Pennsylvania State College, State College, Pa. and former visiting Soil Scientist, University of Puerto Rico; Head, soils Department, Agricultural Experiment Station, University of Puerto Rico, Río Piedras, P. R.; and Soil Scientist, BPI-SCS Research Project.

2 Numbers in parentheses refer to Literature Cited, p. 139.

3 Thanks are expressed to A. García-Porrata, Miss Socorro M. Gaztambide, Assistant Chemist, Institute of Tropical Agriculture, and F. Penne, Jr., assigned to do the laboratory work. 
thin sections of the rocks, prepared by G. S. Rév of New York, were sent to Dr. Jeffries at Pennsylvania State College, for mineral identification. Dr. Jeffries was appointed Visiting Soil Scientist of the University of Puerto Rico for the 3-month period between February 8 and May 4, 1950 and while at the Experiment Station studied the final data and reorganized it for publication.

\section{SOILS STUDIED}

With the idea of increasing knowledge of the mineral character of the tropical soils of Puerto Rico, profile samples were secured in 1943 of the principal soil series of Puerto Rico. Special care was exercised to select typical profiles and the Soil Survey of Puerto Rico (13) was used at all times in deciding the areas from which samples were obtained. Where possible samples of rock formations associated with the soils were obtained to be studied also if it appeared desirable. In all, 42 soil profiles were sampled which included 118 soil samples and 76 rock samples.

The soils considered in this report are described by Roberts (13) as deep upland soils (including some medium-deep soils here), shallow upland soils, inner plains soils, medium friable terraces and alluvial fans, compact soils of terraces and alluvial fans, compact coastal plains, friable coastal plains and very friable coastal plains, well-drained river flood plains and poorly drained river flood plains. These soils belong to the zonal, intrazonal and azonal orders.

Table 1 shows the soil series, the physiographic areas where they occur, and the locations at which the samples were secured; it includes 41 soil types of the 42 soil profiles sampled. In table 2 the soil types are classified as soil series according to soil groups (13).

\section{METHODS OF ANALYSIS}

The methods of analysis used in this study were petrographic and $\mathrm{X}$ ray procedures especially adapted for soils $(10,12)$.

All samples were air-dried, screened to pass a 20 -mesh screen using as little grinding as possible. Free iron oxides were removed using the nascenthydrogen methods of Jeffries $(6,7)$. After the removal of the free iron oxides the samples were dispersed and separated in their sand, silt and clay fractions. The very fine sand fraction $0.10-0.05 \mathrm{~mm}$., was examined petrographically using the methods discussed by Marshall and Jeffries (12). No heavy mineral separations were carried out, as this study was confined to the constituent mineral groups referred to previously. The very fine sand, silt, and clay fractions were studied by $\mathrm{X}$-ray methods using the Geiger Counter X-ray spectrometer as described by Jeffries (8). The patterns obtained were compared with those of minerals of known 
TABLE 1.-Soil series studied, physiographic areas where they occur, and location of samples

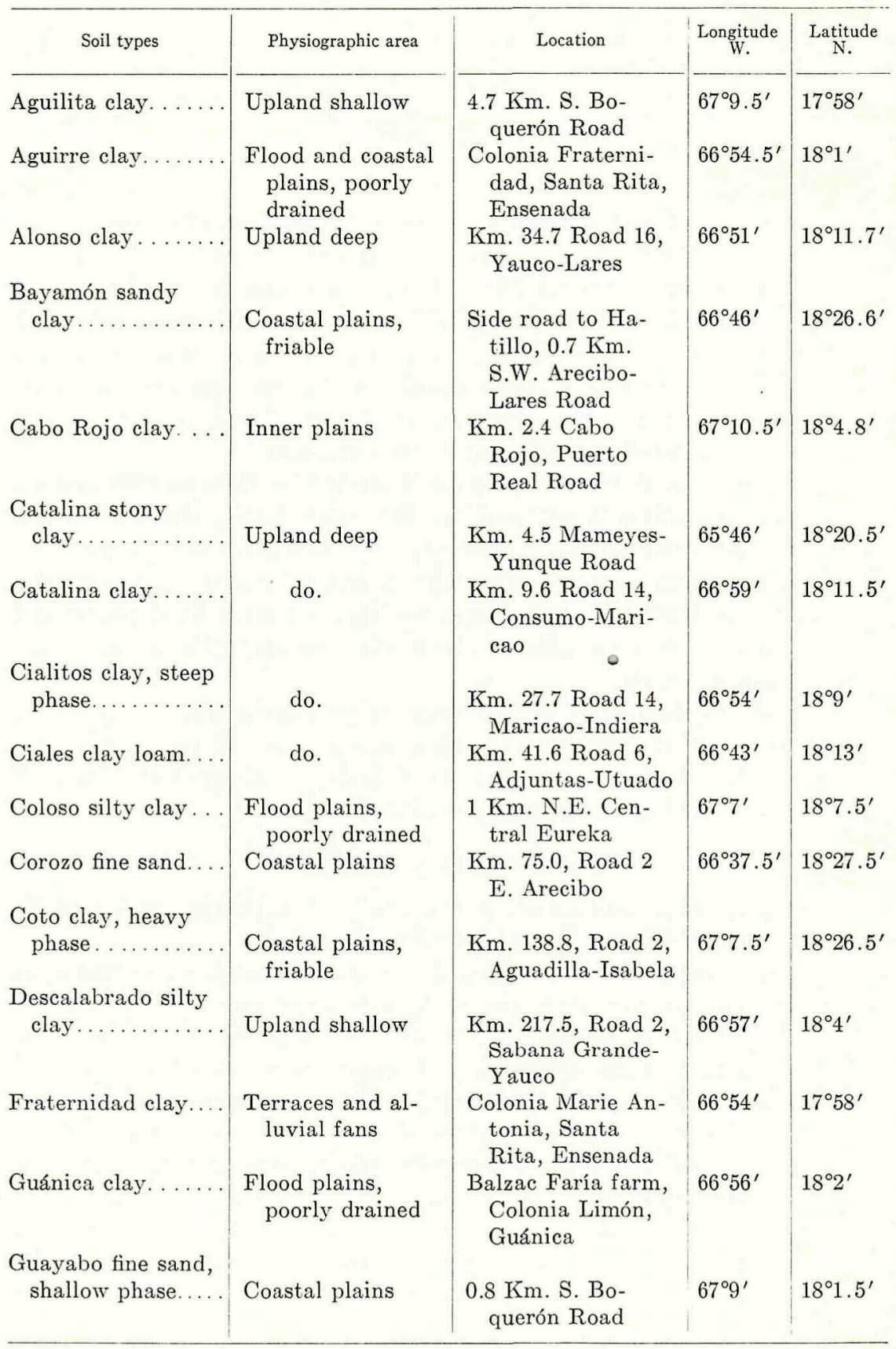




\begin{tabular}{|c|c|c|c|c|}
\hline Soil types & Physiographic area & Location & $\begin{array}{l}\text { Longitude } \\
\text { W. }\end{array}$ & $\begin{array}{l}\text { Latitude } \\
\text { N. }\end{array}$ \\
\hline \multicolumn{5}{|l|}{ Humacao clay } \\
\hline loam........... & $\begin{array}{l}\text { Terraces and al- } \\
\text { luvial fans, } \\
\text { medium friable }\end{array}$ & $\begin{array}{l}\mathrm{Km} .85 .0 \text { Road } 3 \\
\text { Humacao-Ya- } \\
\text { bucoa }\end{array}$ & $65^{\circ} 48.5^{\prime}$ & $18^{\circ} 8^{\prime}$ \\
\hline Islote loamy sand... & Coastal plains & $\begin{array}{l}3 \mathrm{Km} . \mathrm{W} . \text { Arecibo, } \\
\text { Road } 2\end{array}$ & $66^{\circ} 45.5^{\prime}$ & $18^{\circ} 28^{\prime}$ \\
\hline Jácana clay .... & Upland shallow & $\begin{array}{l}\mathrm{Km} .11 .3 \text { Road } 18, \\
\text { Cabo Rojo, Bo- } \\
\text { querón }\end{array}$ & $67^{\circ} 8.5^{\prime}$ & $18^{\circ} 3.5^{\prime}$ \\
\hline Juncos clay. ........ & Upland deep & $\begin{array}{l}\text { Km. } 7.9 \text { Road 5, } \\
\text { Caguas-Gurabo }\end{array}$ & $65^{\circ} 58^{\prime}$ & $18^{\circ} 15.5^{\prime}$ \\
\hline Lares clay.......... & $\begin{array}{l}\text { Terraces, medium } \\
\text { friable }\end{array}$ & $\begin{array}{l}\text { Km. } 5.8 \text { Road } 8 \text {, } \\
\text { Moca-San Se- } \\
\text { bastián }\end{array}$ & $67^{\circ} 6.5^{\prime}$ & $18^{\circ} 23^{\prime}$ \\
\hline \multicolumn{5}{|l|}{ Las Piedras clay } \\
\hline loam. . . . . . . . & Inner plain & $\begin{array}{l}\text { Km. } 23.7 \text { Road } 5 \text {, } \\
\text { Las Piedras-Hu- } \\
\text { macao }\end{array}$ & $65^{\circ} 52^{\prime}$ & $18^{\circ} 11^{\prime}$ \\
\hline Los Guineos clay... & Upland, deep & $\begin{array}{l}\text { Km. 13.6 Mameyes- } \\
\text { Yunque Road }\end{array}$ & $65^{\circ} 47^{\prime}$ & $18^{\circ} 18.5^{\prime}$ \\
\hline Mabí clay........... & Inner plain & $\begin{array}{l}4 \mathrm{Km} \text {. E. Cabo } \\
\text { Rojo, Road 29, } \\
\text { Cabo Rojo-San } \\
\text { Germán }\end{array}$ & $67^{\circ} 6^{\prime}$ & $18^{\circ} 5.5^{\prime}$ \\
\hline Maleza loamy sand. & $\begin{array}{c}\text { Ceastal plains, } \\
\text { very friable }\end{array}$ & $\begin{array}{l}4 \mathrm{Km} . \mathrm{N} \text {. Cabo } \\
\text { Rojo, Lighthouse }\end{array}$ & $67^{\circ} 12^{\prime}$ & $17^{\circ} 57^{\prime}$ \\
\hline Matanzas clay.... & do. & $\begin{array}{l}\text { Entrance Camp } \\
\text { Borinquen, } 0.3 \\
\text { Km. from Road } 2\end{array}$ & $67^{\circ} 8.5^{\prime}$ & $18^{\circ} 27^{\prime}$ \\
\hline Moca clay...... & Inner plain & $\begin{array}{l}\text { Km. } 151.1 \text { Road 2, } \\
\text { E. Aguada }\end{array}$ & $67^{\circ} 11^{\prime}$ & $18^{\circ} 23.5^{\prime}$ \\
\hline \multicolumn{5}{|l|}{ Múcara silty clay } \\
\hline loam. . . . . . . . & Upland, deep & $\begin{array}{l}\text { Barrio Llanos } \\
\text { Tuna, } 1 \mathrm{Km} \text {. E. } \\
\text { of } \mathrm{Km} .11 .3 \text { Road } \\
\text { 18, Cabo Rojo- } \\
\text { Boquerón }\end{array}$ & $67^{\circ} 8^{\prime}$ & $18^{\circ} 3^{\prime}$ \\
\hline Nipe clay........... & Upland, deep & $\begin{array}{l}\text { Km. 10, Mayaguez- } \\
\text { Joyuda Road }\end{array}$ & $67^{\circ} 11^{\prime}$ & $18^{\circ} 9^{\prime}$ \\
\hline $\begin{array}{l}\text { Pandura sandy } \\
\text { clay loam........ }\end{array}$ & do. & $\begin{array}{l}\mathrm{Km} .16 \text { Road } 5, \\
\text { Juncos-Las } \\
\text { Piedras }\end{array}$ & $66^{\circ} 54^{\prime}$ & $18^{\circ} 12.5^{\prime}$ \\
\hline $\begin{array}{l}\text { Paso Seco silty } \\
\text { clay........... }\end{array}$ & $\begin{array}{l}\text { Terraces and al- } \\
\text { luvial fans }\end{array}$ & $\begin{array}{l}\text { Hacienda Verda- } \\
\text { guer of Central } \\
\text { Aguirre, Gua- } \\
\text { yama }\end{array}$ & $66^{\circ} 7^{\prime}$ & $17^{\circ} 57^{\prime}$ \\
\hline
\end{tabular}


TABLE 1.-Concluded

\begin{tabular}{|c|c|c|c|c|}
\hline Soil types & Physiographic area & Location & $\begin{array}{c}\text { Longitude } \\
\text { W. }\end{array}$ & $\begin{array}{l}\text { Latitude } \\
\text { N. }\end{array}$ \\
\hline Río Piedras clay... & Upland, deep & $\begin{array}{l}\text { Exp. Station, Río } \\
\text { Piedras, La } \\
\text { Ceiba field }\end{array}$ & $66^{\circ} 3.5^{\prime}$ & $18^{\circ} 23.3^{\prime}$ \\
\hline $\begin{array}{l}\text { Sabana Seca sandy } \\
\text { clay loam.......... }\end{array}$ & $\begin{array}{l}\text { Coastal plains, } \\
\text { compact }\end{array}$ & $\begin{array}{l}\text { Km. } 2.7 \text { Road } 46, \\
\text { Río Piedras- } \\
\text { Sanatorio }\end{array}$ & $66^{\circ} 4^{\prime}$ & $18^{\circ} 23.5^{\prime}$ \\
\hline St. Lucie fine sand.. & do. & $\begin{array}{l}0.3 \mathrm{Km} . \mathrm{W} . \mathrm{Km} \text {. } \\
\text { 3.3 Arecibo-Lares } \\
\text { Road }\end{array}$ & $66^{\circ} 45.5^{\prime}$ & $18^{\circ} 27.4^{\prime}$ \\
\hline San Antón loam.... & $\begin{array}{l}\text { Flood plains, well } \\
\text { drained }\end{array}$ & $\begin{array}{l}\text { Hacienda Espe- } \\
\text { ranza of Central } \\
\text { Aguirre, Salinas }\end{array}$ & $66^{\circ} 16^{\prime}$ & $17^{\circ} 57.5^{\prime}$ \\
\hline Santa Isabel clay... & $\begin{array}{l}\text { Terraces and al- } \\
\text { luvial fans, } \\
\text { compact }\end{array}$ & $\begin{array}{l}\text { Hacienda Teresa of } \\
\text { Central Aguirre, } \\
\text { Salinas }\end{array}$ & $66^{\circ} 16.5^{\prime}$ & $17^{\circ} 58^{\prime}$ \\
\hline $\begin{array}{l}\text { Soller clay loam, } \\
\text { shallow phase.. }\end{array}$ & Upland, deep & $\begin{array}{l}\text { Km. } 25.9 \text { Road } 34 \\
\text { San Sebastián- } \\
\text { Guajataca }\end{array}$ & $66^{\circ} 59^{\prime}$ & $18^{\circ} 21^{\prime}$ \\
\hline $\begin{array}{l}\text { Tanamá stony } \\
\text { clay........... }\end{array}$ & Upland, shallow & $\begin{array}{l}\text { Km. } 149.1 \text { Road } 2 \text {, } \\
\text { E. Aguada }\end{array}$ & $67^{\circ} 10^{\prime}$ & $18^{\circ} 23.5^{\prime}$ \\
\hline Teja loam. ......... & Upland, deep & $\begin{array}{l}\text { Km. } 92.3 \text { Road } 3 \text {, } \\
\text { Humacao-Ya- } \\
\text { bucoa }\end{array}$ & $65^{\circ} 50.7^{\prime}$ & $18^{\circ} 5.7^{\prime}$ \\
\hline Toa silty clay loam. & $\begin{array}{l}\text { Flood plains, well } \\
\text { drained }\end{array}$ & $\begin{array}{l}\text { Finca Javieri, Cen- } \\
\text { tral Eureka, } 1.9 \\
\text { Km. S. Hormi- } \\
\text { gueros }\end{array}$ & $67^{\circ} 8^{\prime}$ & $18^{\circ} 7^{\prime}$ \\
\hline Utuado loam. . & Upland, deep & $\begin{array}{l}\text { Demonstration } \\
\text { farm, Utuado }\end{array}$ & $66^{\circ} 42^{\prime}$ & $18^{\circ} 16^{\prime}$ \\
\hline Viví sandy loam.... & $\begin{array}{l}\text { Flood plains, well } \\
\text { drained }\end{array}$ & $\begin{array}{l}\text { Km. } 97.6 \text { Road } 3, \\
\text { Humacao-Yabucoa }\end{array}$ & $65^{\circ} 52.5^{\prime}$ & $18^{\circ} 4^{\prime}$ \\
\hline
\end{tabular}

composition and the presence and abundance of the various mineral groups estimated.

THE MINERALS OF THE ROCKS

The rock samples secured along with the soils consisted of andesites, quartz diorites, basalts, serpentines, limestones, sandstones, and shales. The minerals identified in these rocks in standard thin sections are given in table 3 .

The important minerals from the standpoint of soil formation are 


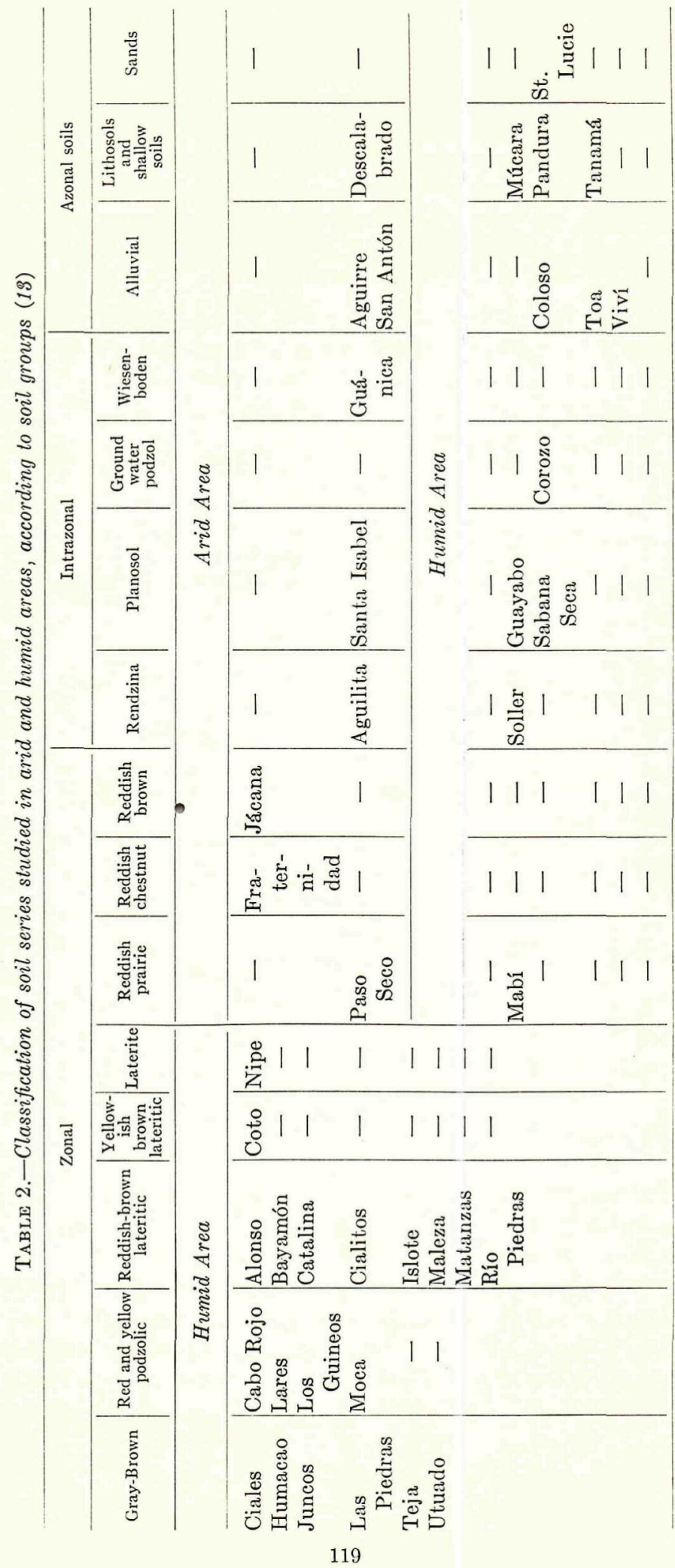


quartz, the feldspars, hornblende, and biotite. It is of interest to note the lack of microcline, orthoclase, muscovite, and certain common accessories notably, tourmaline. The only mineral noted that contains appreciable potassium is biotite.

\section{MECHANICAL ANALYSIS OF THE SOILS}

Before mechanical analysis the free iron oxides were removed using the nascent hydrogen methods described by Jeffries $(6,7)$. Then the iron-free soils were dispersed and separated into their sand, silt, and clay fractions. The very fine sand fraction was separated from the total sands by methods described by Marshall and Jeffries (12).

Table 4 shows the soil series, arranged in physiographic areas, depth of sampling, the content of the various size separates, and the loss on removal of the free iron oxides.

TABLE 3.-Minerals present in rocks of Puerto Rico collected

\begin{tabular}{l|l|l|l}
\hline Quartz & Hornblende & Apatite & Magnetite \\
Albite & Augite & Hypersthene & Chromite \\
Oligoclase & Biotite & Olivine & Calcite \\
Andesine & Chlorite & Zircon & Cordierite \\
Labradorite & Serpentine & Rutile & Sericite \\
& Titanite & - & Epidote \\
\hline
\end{tabular}

THE CONSTITUENT MINERALS OF THE SOILS

The constituent minerals as determined in this study consisted of the quartz, feldspar, and clay-mineral groups. As was previously stated another group of minerals is of great importance in soils in general-the muscovite mica group, but no muscovite mica was identified in any of the soils studied. This is of interest and will be discussed later. Therefore, three constituent mineral groups will be considered. In general, quartz was identified in all the very fine sand and silt fractions and in some clay fractions. Feldspar occurred in varying quantities in 21 of the profiles studied and was entirely absent, or was present in minute traces only, in the other profiles. The chief feldspars identified were oligoclase, albite, and andesine, with varying small amounts of labradorite and, in a very few cases, extremely small quantities of orthoclase. In most cases the feldspar fraction was a mixture of these feldspars. As a rule, however, one feldspar was the most abundant and it was generally, albite or oligoclase.

The distribution of feldspar in the soil profiles was of decided interest. In some cases the quantities of feldspar decreased with depth, and quartz increased; in other cases the reverse was true. Some of the inferences from this finding will be discussed later. 
TABLE 4.-Mechanical analyses of soil samples by physiographic regions

\begin{tabular}{|c|c|c|c|c|c|c|c|}
\hline Soil series & Sample No. & Depth & $\begin{array}{l}\text { Coarse } \\
\text { sand }\end{array}$ & $\begin{array}{l}\text { Very } \\
\text { fine } \\
\text { sand }\end{array}$ & Silt & Clay & $\begin{array}{l}\text { Lost on } \\
\text { cleaning } 1\end{array}$ \\
\hline \multicolumn{8}{|c|}{ Upland deep } \\
\hline \multirow{3}{*}{ Alonso } & & Inclies & Percent & Percent & Percent & Percent & Percent \\
\hline & 91 & $8-18$ & 5.75 & 5.93 & 34.67 & 23.50 & 30.15 \\
\hline & 90 & $18-32$ & 7.29 & 6.76 & 26.75 & 22.00 & 37.20 \\
\hline \multirow[t]{2}{*}{ Catalina } & 172 & 2 & 2.65 & 8.80 & 19.23 & 26.27 & 43.05 \\
\hline & 81 & 3 & .93 & 4.37 & 22.82 & 43.95 & 27.93 \\
\hline Cialitos & 84 & $33-20$ & .37 & 2.68 & 28.35 & 45.00 & 23.60 \\
\hline- & 83 & $33-45$ & 1.30 & 5.65 & 15.20 & 48.30 & 29.55 \\
\hline \multirow[t]{2}{*}{ Ciales } & 93 & 2 & 16.48 & 25.95 & 41.62 & 9.15 & 6.80 \\
\hline & 92 & 3 & 52.04 & 20.87 & 9.89 & 9.25 & 7.95 \\
\hline \multirow[t]{2}{*}{ Juncos } & 58 & $0-8$ & 6.06 & 15.92 & 23.72 & 33.05 & 21.25 \\
\hline & 57 & $8-15$ & 13.46 & 13.40 & 32.29 & 26.35 & 14.50 \\
\hline \multirow[t]{4}{*}{ Los Guineos } & 186 & $0-24$ & 77.60 & 5.70 & 2.25 & 3.70 & 10.75 \\
\hline & 185 & $24-43$ & 55.90 & 6.15 & 10.27 & 23.15 & 4.53 \\
\hline & 184 & $32-48$ & 37.35 & 8.45 & 15.65 & 17.36 & 21.19 \\
\hline & 183 & $48+$ & 38.75 & 10.05 & 16.65 & 17.20 & 17.35 \\
\hline \multirow[t]{4}{*}{ Múcara } & 9 & $0-10$ & 22.79 & 13.40 & 9.90 & 24.55 & 29.36 \\
\hline & 8 & $10-18$ & 38.90 & 17.10 & 7.50 & 13.26 & 23.24 \\
\hline & 7 & $18-30$ & 54.85 & 10.95 & 3.70 & 10.05 & 20.45 \\
\hline & 6 & $30+$ & 39.55 & 14.00 & 3.55 & 13.35 & 29.55 \\
\hline \multirow[t]{6}{*}{ Nipe } & 16 & $0-16$ & 36.00 & 10.54 & 3.10 & 23.30 & 27.06 \\
\hline & 17 & $16-36$ & 6.59 & .87 & .95 & 28.65 & 62.94 \\
\hline & 18 & $36-120$ & 14.35 & .58 & .80 & 20.12 & 64.15 \\
\hline & 19 & $120-240$ & .81 & .20 & .33 & 18.42 & 80.24 \\
\hline & 156 & 4 & 12.25 & 4.92 & 2.68 & 25.97 & 54.18 \\
\hline & 157 & 4 & 5.78 & 3.05 & 3.40 & 44.37 & 43.40 \\
\hline \multirow[t]{3}{*}{ Pandura } & 62 & $0-12$ & 65.69 & 16.91 & 4.40 & 6.45 & 6.55 \\
\hline & 61 & $12-24$ & 73.45 & 5.20 & 3.90 & 8.35 & 9.10 \\
\hline & 60 & $24+$ & 47.35 & 7.10 & 7.60 & 28.55 & 9.40 \\
\hline Soller & 117 & 2 & .75 & 2.25 & 5.80 & 53.80 & 37.40 \\
\hline \multirow[t]{2}{*}{ Teja } & 71 & $0-12$ & 43.72 & 25.92 & 11.41 & 12.35 & 6.60 \\
\hline & 70 & $12+$ & 64.25 & 5.50 & 7.70 & 10.40 & 12.15 \\
\hline
\end{tabular}


TABLE 4.-Continued

\begin{tabular}{|c|c|c|c|c|c|c|c|}
\hline Soil series & Sample No. & Depth & $\begin{array}{l}\text { Coarse } \\
\text { sand }\end{array}$ & $\begin{array}{l}\text { Very } \\
\text { fine } \\
\text { sand }\end{array}$ & Silt & Clay & $\begin{array}{l}\text { Lost on } \\
\text { cleaning }\end{array}$ \\
\hline \multicolumn{8}{|c|}{ Upland deep (continued) } \\
\hline \multirow{5}{*}{ Utuado } & & Inches & Percent & Percent & Percent & Percent & Percent \\
\hline & 98 & $0-24$ & 59.30 & 11.75 & 8.85 & 11.35 & 8.75 \\
\hline & 97 & $24-56$ & 14.00 & 30.80 & 22.10 & 19.40 & 13.70 \\
\hline & 96 & $56-64$ & 26.65 & 26.25 & 19.45 & 13.85 & 13.80 \\
\hline & 95 & $72-64$ & 71.40 & 10.55 & 5.10 & 6.45 & 6.50 \\
\hline Río Piedras & 190 & 2 & 4.10 & 3.68 & 12.70 & 62.17 & 17.35 \\
\hline \multicolumn{8}{|c|}{ Upland shallow } \\
\hline Aguilita & 103 & $0-12$ & 4.14 & 3.96 & 27.71 & 29.66 & 34.53 \\
\hline Tanamá & 109 & 2 & 12.90 & 10.35 & 22.15 & 36.70 & 17.90 \\
\hline \multirow[t]{3}{*}{ Descalabrado } & 23 & $0-10$ & 28.90 & 17.80 & 15.20 & 20.05 & 18.05 \\
\hline & 24 & $10-24$ & 17.77 & 20.90 & 20.45 & 26.55 & 14.33 \\
\hline & 25 & $24+$ & 29.10 & 20.04 & 16.95 & 21.75 & 12.16 \\
\hline \multirow[t]{2}{*}{ Jácana } & 4 & $0-7$ & 14.50 & 13.05 & 18.85 & 23.46 & 30.14 \\
\hline & 3 & $7-12$ & 20.10 & 10.55 & 13.89 & 23.80 & 31.66 \\
\hline \multicolumn{8}{|c|}{ Inner plains } \\
\hline \multirow[t]{3}{*}{ Cabo Rojo } & 135 & $0-24$ & 21.07 & 13.25 & 25.50 & 26.35 & 13.83 \\
\hline & 134 & $24-36$ & 12.30 & 13.58 & 29.32 & 34.25 & 10.55 \\
\hline & 132 & $36+$ & 10.12 & 14.16 & 22.12 & 32.80 & 20.80 \\
\hline \multirow[t]{4}{*}{ Las Piedras } & 66 & $0-20$ & 59.30 & 11.27 & 7.03 & 15.50 & 6.90 \\
\hline & 65 & $20-44$ & 61.80 & 9.35 & 4.10 & 14.85 & 9.90 \\
\hline & 64 & $44-48$ & 47.35 & 7.10 & 7.60 & 28.55 & 9.40 \\
\hline & 63. & $48+$ & 73.45 & 5.20 & 3.90 & 8.35 & 9.10 \\
\hline \multirow[t]{3}{*}{ Mabí } & 15 & $0-10$ & 13.05 & 21.95 & 14.80 & 24.25 & 25.95 \\
\hline & 14 & $10-30$ & 12.05 & 19.69 & 13.20 & 31.45 & 23.61 \\
\hline & 13 & $30+$ & 17.75 & 14.25 & 11.10 & 27.30 & 29.60 \\
\hline Moca & 106 & 2 & 3.60 & 12.60 & 7.20 & 46.60 & 30.00 \\
\hline \multicolumn{8}{|c|}{ Terraces and alluvial fans-medium friable } \\
\hline \multirow[t]{2}{*}{ Humacao } & 68 & $0-20$ & 37.62 & 26.26 & 12.12 & 14.70 & 9.30 \\
\hline & 67 & $20-44$ & 23.30 & 20.05 & 16.80 & 28.90 & 10.95 \\
\hline \multirow[t]{2}{*}{ Lares } & 114 & $0-60$ & 11.48 & 7.75 & 12.92 & 35.25 & 32.60 \\
\hline & 113 & $60+$ & 11.00 & 5.80 & 13.95 & 44.95 & 24.30 \\
\hline
\end{tabular}


TABLE 4.-Continued

\begin{tabular}{|c|c|c|c|c|c|c|c|}
\hline Soil series & Sample No. & Depth & $\begin{array}{l}\text { Coarse } \\
\text { sand }\end{array}$ & $\begin{array}{l}\text { Very } \\
\text { fine } \\
\text { sand }\end{array}$ & Silt & Clay & $\begin{array}{l}\text { Lost on } \\
\text { cleaning }\end{array}$ \\
\hline \multicolumn{8}{|c|}{ Terraces and alluvial fans-compact } \\
\hline Fraternidad & $\begin{array}{l}30 \\
39 \\
28 \\
28 B\end{array}$ & $\begin{array}{c}\text { Inches } \\
0-7 \\
7-18 \\
18-36 \\
36+\end{array}$ & $\begin{array}{l}\text { Percent } \\
35.48 \\
30.75 \\
16.40 \\
18.65\end{array}$ & $\begin{array}{r}\text { Percent } \\
15.30 \\
9.95 \\
11.45 \\
12.10\end{array}$ & $\begin{array}{l}\text { Percent } \\
10.30 \\
13.40 \\
14.40 \\
11.10\end{array}$ & $\begin{array}{l}\text { Percent } \\
28.40 \\
44.25 \\
40.05 \\
41.01\end{array}$ & $\begin{array}{r}\text { Percent } \\
10.52 \\
1.65 \\
17.70 \\
17.14\end{array}$ \\
\hline Paso Seco & $\begin{array}{l}37 \\
36 \\
35\end{array}$ & $\begin{array}{r}0-10 \\
10-18 \\
22-35\end{array}$ & $\begin{array}{l}25.15 \\
35.10 \\
17.37\end{array}$ & $\begin{array}{l}20.55 \\
18.00 \\
28.23\end{array}$ & $\begin{array}{l}11.05 \\
11.35 \\
17.35\end{array}$ & $\begin{array}{l}28.80 \\
12.90 \\
22.70\end{array}$ & $\begin{array}{l}14.45 \\
22.65 \\
14.35\end{array}$ \\
\hline Santa Isabel & $\begin{array}{l}44 \\
43 \\
42\end{array}$ & $\begin{array}{c}0-8 \\
8-16 \\
16-24\end{array}$ & $\begin{array}{l}21.54 \\
46.10 \\
28.95\end{array}$ & $\begin{array}{l}23.59 \\
10.37 \\
10.80\end{array}$ & $\begin{array}{r}18.32 \\
8.17 \\
9.15\end{array}$ & $\begin{array}{l}22.75 \\
23.41 \\
27.30\end{array}$ & $\begin{array}{l}13.80 \\
11.95 \\
23.80\end{array}$ \\
\hline \multicolumn{8}{|c|}{ Coastal plains } \\
\hline Sabana Seca & $\begin{array}{l}194 \\
193\end{array}$ & $\begin{array}{c}0-12 \\
12+\end{array}$ & $\begin{array}{l}57.05 \\
80.75\end{array}$ & $\begin{array}{l}5.45 \\
9.72\end{array}$ & $\begin{array}{l}6.30 \\
5.70\end{array}$ & $\begin{array}{r}21.50 \\
3.83\end{array}$ & $\begin{array}{l}9.70 \\
-\end{array}$ \\
\hline Coto & 122 & 2 & 6.26 & 3.16 & 13.78 & 23.00 & 53.80 \\
\hline Bayamón & $\begin{array}{l}165 \\
164\end{array}$ & $\begin{array}{r}0-18 \\
18-24\end{array}$ & $\begin{array}{l}50.83 \\
14.90\end{array}$ & $\begin{array}{l}7.62 \\
2.10\end{array}$ & $\begin{array}{l}2.37 \\
1.20\end{array}$ & $\begin{array}{l}25.25 \\
59.70\end{array}$ & $\begin{array}{l}13.93 \\
22.10\end{array}$ \\
\hline Matanzas & 119 & 2 & 1.75 & 2.25 & 5.80 & 53.80 & 37.40 \\
\hline Corozo & $\begin{array}{l}147 \\
150\end{array}$ & $\begin{array}{l}0-2 \\
2-12\end{array}$ & $\begin{array}{l}93.75 \\
91.90\end{array}$ & $\begin{array}{l}1.15 \\
1.00\end{array}$ & $\begin{array}{l}.20 \\
.20\end{array}$ & $\begin{array}{l}3.05 \\
3.30\end{array}$ & $\begin{array}{l}1.85 \\
3.60\end{array}$ \\
\hline Guayabo & $\begin{array}{l}105 \\
104\end{array}$ & $\begin{array}{l}12-36 \\
36+\end{array}$ & $\begin{array}{l}71.02 \\
52.30\end{array}$ & $\begin{array}{r}12.93 \\
2.05\end{array}$ & $\begin{array}{l}5.22 \\
1.50\end{array}$ & $\begin{array}{r}5.65 \\
28.80\end{array}$ & $\begin{array}{r}5.18 \\
15.35\end{array}$ \\
\hline Islote & 141 & $0-40$ & 89.00 & 1.90 & 1.75 & 1.30 & 6.05 \\
\hline Maleza & 101 & 2 & 89.85 & .95 & .80 & 3.90 & 4.50 \\
\hline St. Lucie & 169 & 5 & 65.85 & 2.05 & 4.05 & 23.50 & 4.55 \\
\hline \multicolumn{8}{|c|}{ Flood plains } \\
\hline Viví & $\begin{array}{l}73 \\
72\end{array}$ & $\begin{array}{c}0-15 \\
15+\end{array}$ & $\begin{array}{l}43.23 \\
62.06\end{array}$ & $\begin{array}{l}28.14 \\
24.64\end{array}$ & $\begin{array}{l}9.48 \\
6.55\end{array}$ & $\begin{array}{r}14.40 \\
4.30\end{array}$ & $\begin{array}{l}4.75 \\
2.45\end{array}$ \\
\hline
\end{tabular}


TABLE 4.-Concluded

\begin{tabular}{|c|c|c|c|c|c|c|c|}
\hline Soil series & Sample No. & Depth & $\begin{array}{l}\text { Coarse } \\
\text { sand }\end{array}$ & $\begin{array}{l}\text { Very } \\
\text { fine } \\
\text { sand }\end{array}$ & Silt & Clay & $\begin{array}{l}\text { Lost on } \\
\text { cleaning } 1\end{array}$ \\
\hline \multicolumn{8}{|c|}{ Flood plains (continued) } \\
\hline & & Inches & Percent & Percent & Percent & Percent & Percent \\
\hline \multirow[t]{4}{*}{ San Antón } & 41 & $0-24$ & 12.04 & 26.76 & 25.05 & 20.50 & 15.65 \\
\hline & 40 & $24-29$ & 22.84 & 27.61 & 18.25 & 16.80 & 14.50 \\
\hline & 39 & $29-44$ & 15.20 & 21.00 & 12.00 & 22.65 & 29.15 \\
\hline & 38 & $44+$ & 61.60 & 5.85 & 5.00 & 7.75 & 19.80 \\
\hline \multirow[t]{3}{*}{ Toa } & 52 & $0-16$ & 4.45 & 18.45 & 13.85 & 29.55 & 33.70 \\
\hline & 51 & $16-34$ & .92 & 21.30 & 18.88 & 35.30 & 23.60 \\
\hline & 50 & $34-46$ & 3.95 & 11.65 & 15.00 & 39.00 & 30.40 \\
\hline \multirow[t]{2}{*}{ Aguirre } & 31 & $0-10$ & 27.20 & 7.90 & 8.40 & 30.26 & $\cdot 26.24$ \\
\hline & 32 & $10+$ & 12.59 & 17.77 & 17.26 & 31.83 & 20.25 \\
\hline \multirow[t]{4}{*}{ Coloso } & 49 & $0-10$ & 14.60 & 11.45 & 14.45 & 38.95 & 20.55 \\
\hline & 48 & $10-34$ & 5.93 & 8.95 & 19.92 & 45.15 & 20.05 \\
\hline & 47 & $34-52$ & 1.15 & 9.05 & 23.80 & 47.20 & 18.80 \\
\hline & 46 & $52+$ & .98 & 8.32 & 24.17 & 47.68 & 18.85 \\
\hline \multirow[t]{2}{*}{ Guánica } & 34 & 2 & 6.87 & 18.26 & 12.62 & 38.35 & 23.90 \\
\hline & 33 & 3 & 12.20 & 8.77 。 & 11.28 & 41.80 & 25.95 \\
\hline
\end{tabular}

${ }^{1}$ Includes free or hydrated oxides of iron, aluminum and titanium, free silica, carbonates, organic matter, and soluble cations and salts.

2 Surface.

${ }^{3}$ Subsoil.

${ }^{4}$ Soil below concretions.

5 Subsurface.

A few of the very fine sand and silt fractions which contained no feldspar were of interest in that they consisted almost wholly of some quartz and large plates of kaolin. This was particularly true in the Los Guineos soil but was also noted in several other highly weathered soil profiles.

The clay minerals identified were kaolin, illite, montmorillonite, and one identified tentatively as beidellite. The most abundant clay minerals were kaolin and the beidellitelike mineral, illite was next in abundance, followed by montmorillonite. In some cases the clay fractions were mixtures, but in many they were apparently very well-developed single clay minerals. Where illite or chlorite was identified in the upper horizons weathering reactions changed these minerals in the lower horizons to kaolin or beidellite.

The constituent minerals identified in the very fine sand, silt, and clay 
fractions of the soils indicated, and their relative abundance in the soil profile are shown in table 5 . For convenience the soils have been arranged according to the physiographic areas in which they occur.

The method of determining the presence of the various mineral groups was by comparing typical $\mathrm{X}$-ray patterns of the soil fractions with those of known minerals. In addition to X-ray patterns of the very fine sand fractions, petrographic examinations were carried out to determine the presence or absence of small quantities of feldspar which would not be apparent in the X-ray patterns.

\section{DISCUSSION OF FINDINGS}

This study was conducted on the very fine sand, silt, and clay fractions of the soils indicated from which the free iron oxides had been removed. The soils studied were of the zonal, intrazonal and azonal orders and were from 15 of the great soil groups, as shown in table 2. In most cases soil profiles were studied; in a few, however, where it was impossible to secure profile samples, surface soils alone were investigated.

The constituent minerals of soils which have been previously discussed are those of the quartz, feldspar, mica, and clay-mineral groups. Study of the X-ray patterns showed that the muscovite mica group was not present in the soils studied, consequently any comparisons made are based on the quartz, feldspar, and clay-mineral groups. The presence or absence of feldspar in the various soils studied (table 5) showed that in the upland soils, which included a group of 17 soil series, 8 contained feldspars in appreciable quantities, 1 in very small quantities and feldspars were completely absent or were present in only minute traces in the other 8 . Feldspars were present in 2 of the soils of the inner plains, and absent in 2 . The group of soils from the terraces and alluvial fans included 4 soils containing feldspars and one without. All the soils of the coastal plains were practically free of feldspars; the river flood plain soils, however, all contained appreciable quantities Table 6 gives the soil series with and without feldspars.

Further study of the soils which contained feldspars showed that the feldspar content of the various horizons decreased with depth in some soils; in others it increased in the sand and silt fractions as has been previously noted.

Twenty-one of the soil series studied contained feldspars. It was noted that in 9 of these series the feldspar content of the very fine sand and silt fractions decreased with depth in the profile, and in 12 of them the feldspars increased with depth.

The feldspars typical of all soils were of the plagioclase series. The plagioclase feldspar series consists of solid solution mixtures of the albite 


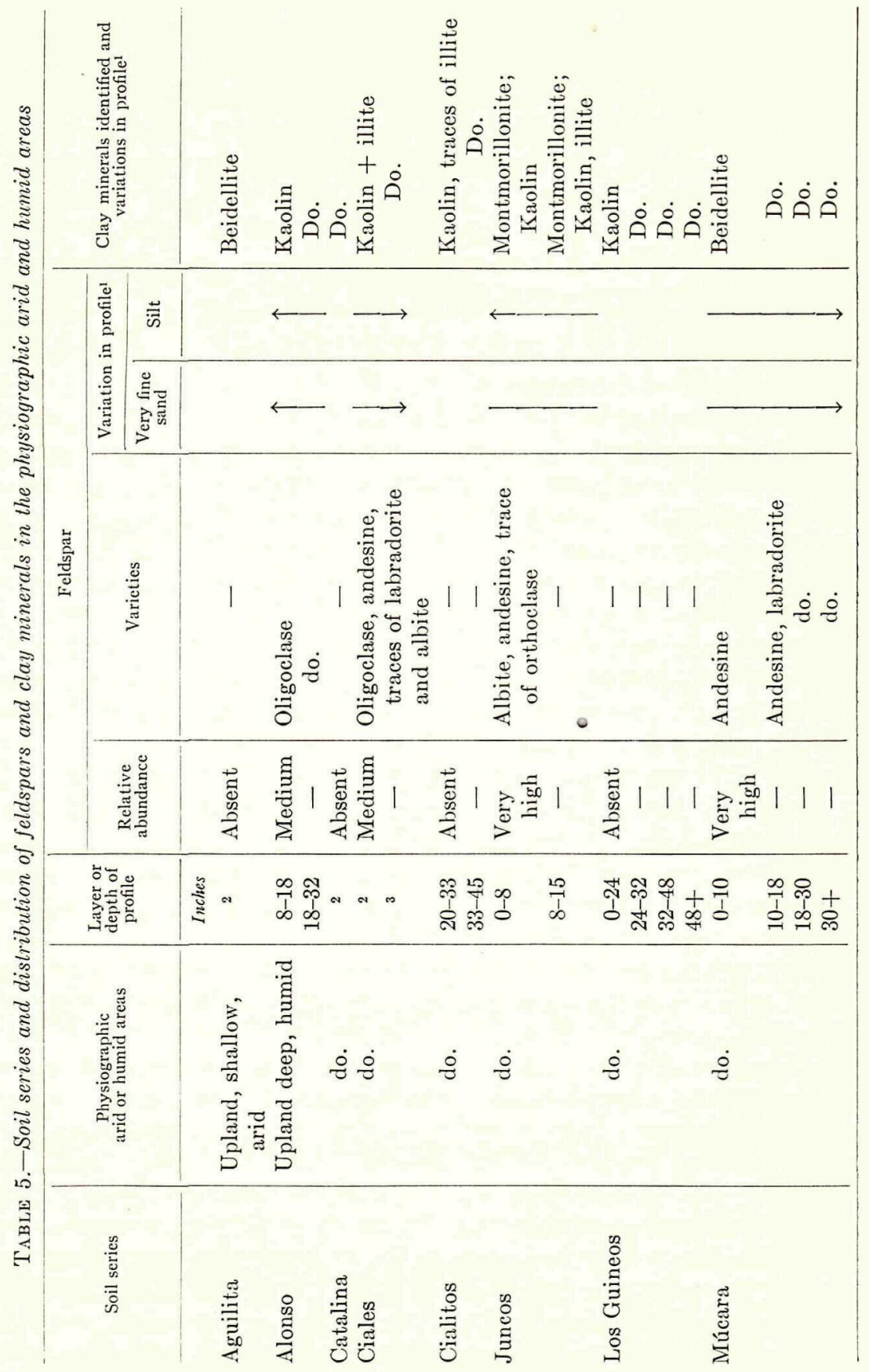




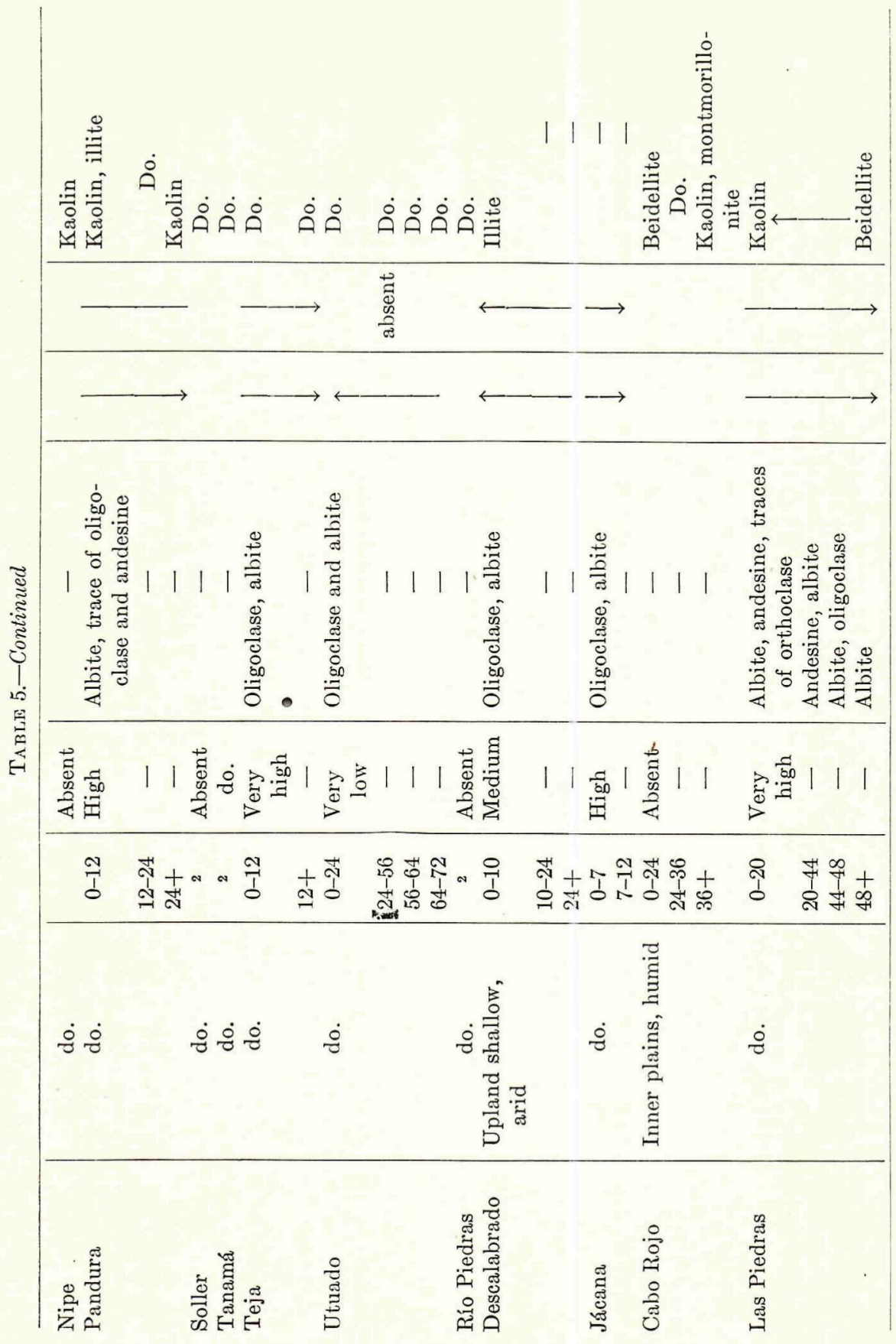




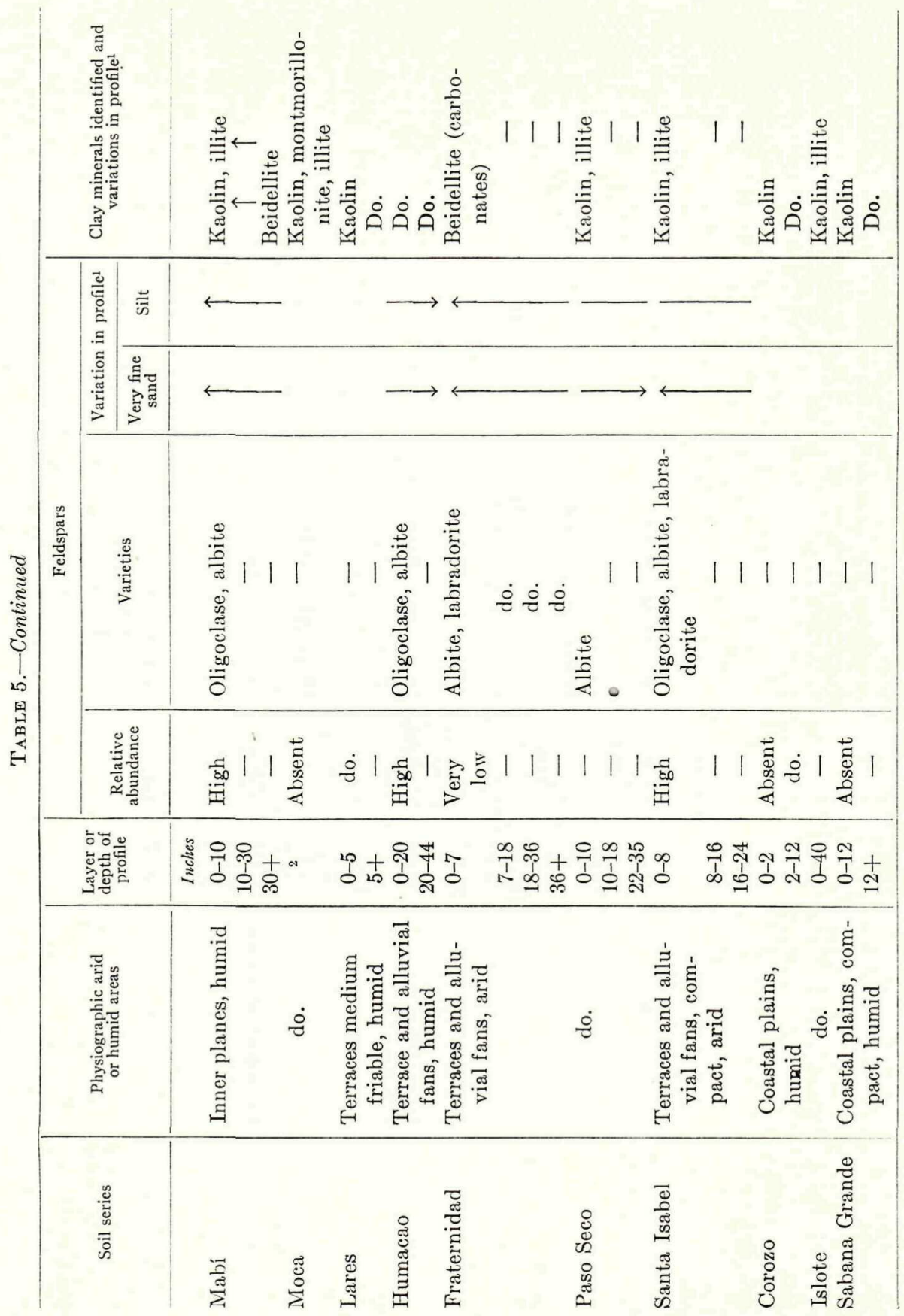


CONSTITUENT MINERALS OF SOME PUERTO RICAN SOILS

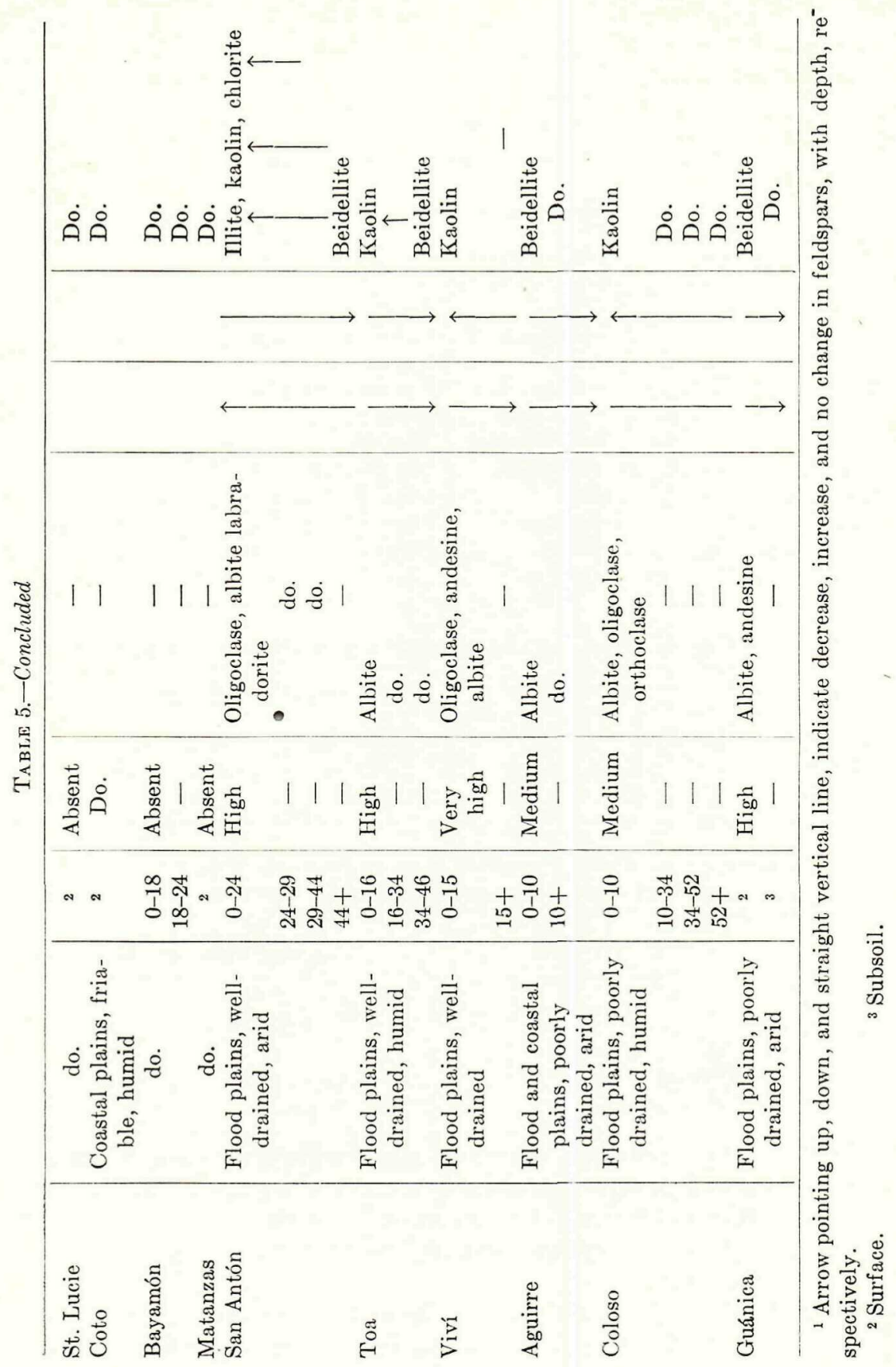


molecule $\mathrm{Ab}$. $\left(\mathrm{Na}_{2} \mathrm{O} \cdot \mathrm{Al}_{2} \mathrm{O}_{3} \cdot 6 \mathrm{SiO}_{2}\right)$ and anorthite $\mathrm{An}$. $\left(\mathrm{CaO} \cdot \mathrm{Al}_{2} \mathrm{O}_{3} \cdot 2 \mathrm{SiO}_{2}\right)$. Albite and anorthite are designated as end members of the series and the intermediate compositions are generally expressed in the percentage distribution of the albite and anorthite molecules. Table 7 gives the plagioclase series, variety names, and limits of composition.

TABLE 6.-Soil series of Puerto Rico studied in which feldspars are present or absent

\begin{tabular}{|c|c|c|c|}
\hline Feldspars present & Feldspars present & Feldspars absent & Feldspars absent \\
\hline Alonso. . & Mabí & Aguilita. & Corozo \\
\hline Ciales.............. & Humacao & Catalina.......... & Maleza \\
\hline Juncos. . . . . . . . . & Viví & Cialitos........ & Guayabo \\
\hline Múcara.... & Fraternidad & Los Guineos... & Islote \\
\hline Pandura... & Paso Seco & Soller........ & Sabana Seca \\
\hline Teja............. & Santa Isabel & Tanamá....... & St. Lucie \\
\hline Utuado............ & San Antón & Río Piedras....... & Coto \\
\hline Descalabrado...... & Toa & Cabo Rojo........ & Bayamón \\
\hline Jácana. . . . . . & Aguirre & Moca......... & Matanzas \\
\hline Las Piedras... & Coloso & Lares............ & Nipe \\
\hline- & Guánica & - & - \\
\hline
\end{tabular}

TABLE 7.-Variety names and composition limits of plagioclase feldspar series

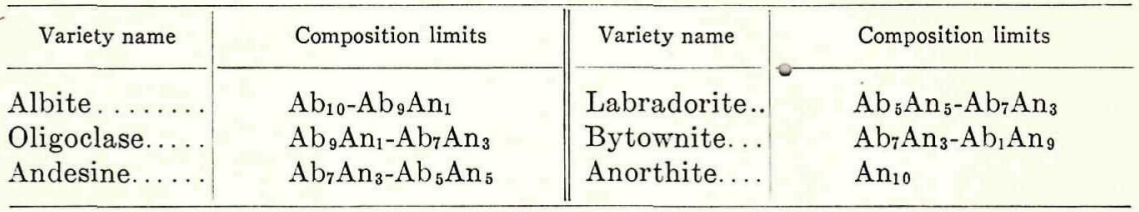

TABLE 8.-Comparison of the clay content of soils containing feldspars and those containing no feldspars in soils of the upland, inner plain, terraces, and alluvial fans

\begin{tabular}{|c|c|c|}
\hline Physiographic group & $\begin{array}{l}\text { Clay content with } \\
\text { feldspars present }\end{array}$ & $\begin{array}{l}\text { Clay content with } \\
\text { feldspars absent }\end{array}$ \\
\hline & Percent & Percent \\
\hline Upland soils..... & 18.24 & 28.50 \\
\hline Inner plain soils........... & 21.48 & 39.41 \\
\hline Terraces and alluvial fans .................... & 15.58 & 40.20 \\
\hline
\end{tabular}

In the 21 soil series that contained appreciable quantities of feldspars the predominant feldspar was albite in 8 cases, oligoclase in 12 , and andesine in 1. Minor quantities of andesine and labradorite were observed in many soils where the very fine sand and silt fractions were predominantly albite or oligoclase.

Study of the mechanical analyses in table 4 showed that, where comparisons could be made, the soils containing appreciable quantities of feldspar 
TABLE 9.-Clay content, cation-exchange capacity, and clay minerals present in the soils from Puerto Rico

\begin{tabular}{|c|c|c|c|c|c|c|}
\hline Great soil group & Soil type & $\begin{array}{c}\text { Sample } \\
\text { No. }\end{array}$ & Depth & $\begin{array}{c}\text { Clay } \\
\text { content }\end{array}$ & \begin{tabular}{|l} 
Cation- \\
exchange \\
capacity
\end{tabular} & $\begin{array}{l}\text { Clay minerals } \\
\text { present } \\
\text { X-Rays }\end{array}$ \\
\hline & & & Inches & Percent & $\begin{array}{l}\text { M.e./100 } \\
\text { gm. soil }\end{array}$ & \\
\hline Reddish Brown & Jácana clay & 3 & $12+^{1}$ & 23.46 & 26.11 & $\begin{array}{l}\text { Beidellite } \\
+ \text { kaoli- } \\
\text { nite } \\
\text { Do. }\end{array}$ \\
\hline $\begin{array}{l}\text { Gray-brown pod- } \\
\text { zolic or lithosol } \\
\text { depending on } \\
\text { depth and slope }\end{array}$ & $\begin{array}{l}\text { Múcara silty } \\
\text { clay loam }\end{array}$ & $\begin{array}{l}6 \\
7 \\
8 \\
9\end{array}$ & $\begin{array}{r}30+ \\
18-30 \\
10-18 \\
0-10\end{array}$ & $\begin{array}{l}13.35 \\
10.05 \\
13.26 \\
24.55\end{array}$ & $\begin{array}{l}36.71 \\
29.75 \\
31.04 \\
36.04\end{array}$ & $\begin{array}{l}\text { Beidellite } \\
\text { Do. } \\
\text { Do. } \\
\text { Do. }\end{array}$ \\
\hline Reddish prairie & Mabí clay & $\begin{array}{l}13 \\
14 \\
15\end{array}$ & $\begin{array}{r}30+ \\
10-30 \\
0-10\end{array}$ & $\begin{array}{l}27.30 \\
31.45 \\
24.25\end{array}$ & $\begin{array}{l}31.65 \\
34.02 \\
31.17\end{array}$ & $\begin{array}{l}\text { Beidellite } \\
\quad \text { - } \\
\text { Kaolinite } \\
\quad+\text { illite }\end{array}$ \\
\hline $\begin{array}{l}\text { Lithosol associated } \\
\text { with Prairie, } \\
\text { Chernozem and } \\
\text { Chestnut soils }\end{array}$ & $\begin{array}{l}\text { Descalabrado } \\
\text { silty clay } \\
\end{array}$ & $\begin{array}{l}23 \\
24 \\
25 \\
26\end{array}$ & $\begin{array}{c}0-10 \\
10-18^{1} \\
24^{3} \\
4\end{array}$ & $\begin{array}{l}20.05 \\
26.55 \\
21.75 \\
29.70\end{array}$ & $\begin{array}{l}16.97 \\
22.27 \\
16.46 \\
19.78\end{array}$ & $\begin{array}{r}\text { Illite } \\
- \\
-\end{array}$ \\
\hline Reddish chestnut & Fraternidad clay & $\begin{array}{l}28 \\
28 \mathrm{~B} \\
29 \\
30\end{array}$ & $\begin{array}{l}18-36 \\
36^{5} \\
7-18^{6} \\
0-7\end{array}$ & $\begin{array}{l}40.05 \\
41.01 \\
44.25 \\
28.40\end{array}$ & $\begin{array}{l}15.19 \\
13.18 \\
11.23 \\
21.03\end{array}$ & $\begin{array}{c}- \\
\text { Beidellite } \\
\text { Do. }\end{array}$ \\
\hline $\begin{array}{l}\text { Alluvial, poorly } \\
\text { drained }\end{array}$ & Aguirre clay & $\begin{array}{l}31 \\
32\end{array}$ & $\begin{array}{l}0-10 \\
10+\end{array}$ & $\begin{array}{l}30.26 \\
31.83\end{array}$ & $\begin{array}{l}42.06 \\
26.20\end{array}$ & $\begin{array}{l}\text { Beidellite } \\
\text { Do. }\end{array}$ \\
\hline Wiesenboden & Guánica clay & $\begin{array}{l}33 \\
34\end{array}$ & $\begin{array}{l}7 \\
2\end{array}$ & $\begin{array}{l}41.80 \\
38.35\end{array}$ & $\begin{array}{l}39.56 \\
43.20\end{array}$ & $\begin{array}{l}\text { Beidellite } \\
\text { Do. }\end{array}$ \\
\hline Reddish prairie & $\begin{array}{l}\text { Paso Seco silty } \\
\text { clay }\end{array}$ & $\begin{array}{l}35 \\
36 \\
37\end{array}$ & $\begin{array}{r}10-18 \\
0-10 \\
22-35\end{array}$ & $\begin{array}{l}22.70 \\
12.90 \\
28.80\end{array}$ & $\begin{array}{l}16.80 \\
20.10 \\
19.62\end{array}$ & $\begin{array}{l}\text { Kaolinite } \\
+ \text { illite } \\
- \\
-\end{array}$ \\
\hline $\begin{array}{l}\text { Alluvial, well- } \\
\text { drained, semiarid } \\
\text { and subhumid } \\
\text { area }\end{array}$ & San Antón loam & $\begin{array}{l}38 \\
39 \\
40 \\
41\end{array}$ & $\begin{array}{r}44+ \\
29-44 \\
24-29 \\
0-24\end{array}$ & $\begin{array}{r}7.75 \\
22.65 \\
16.80 \\
20.50\end{array}$ & $\begin{array}{l}11.16 \\
22.63 \\
18.83 \\
23.74\end{array}$ & $\begin{array}{l}\text { Beidellite } \\
- \\
- \\
\text { Illite + } \\
\text { kaolinite } \\
+ \text { chlo- } \\
\text { rite }\end{array}$ \\
\hline
\end{tabular}


TABLe 9.-Continued

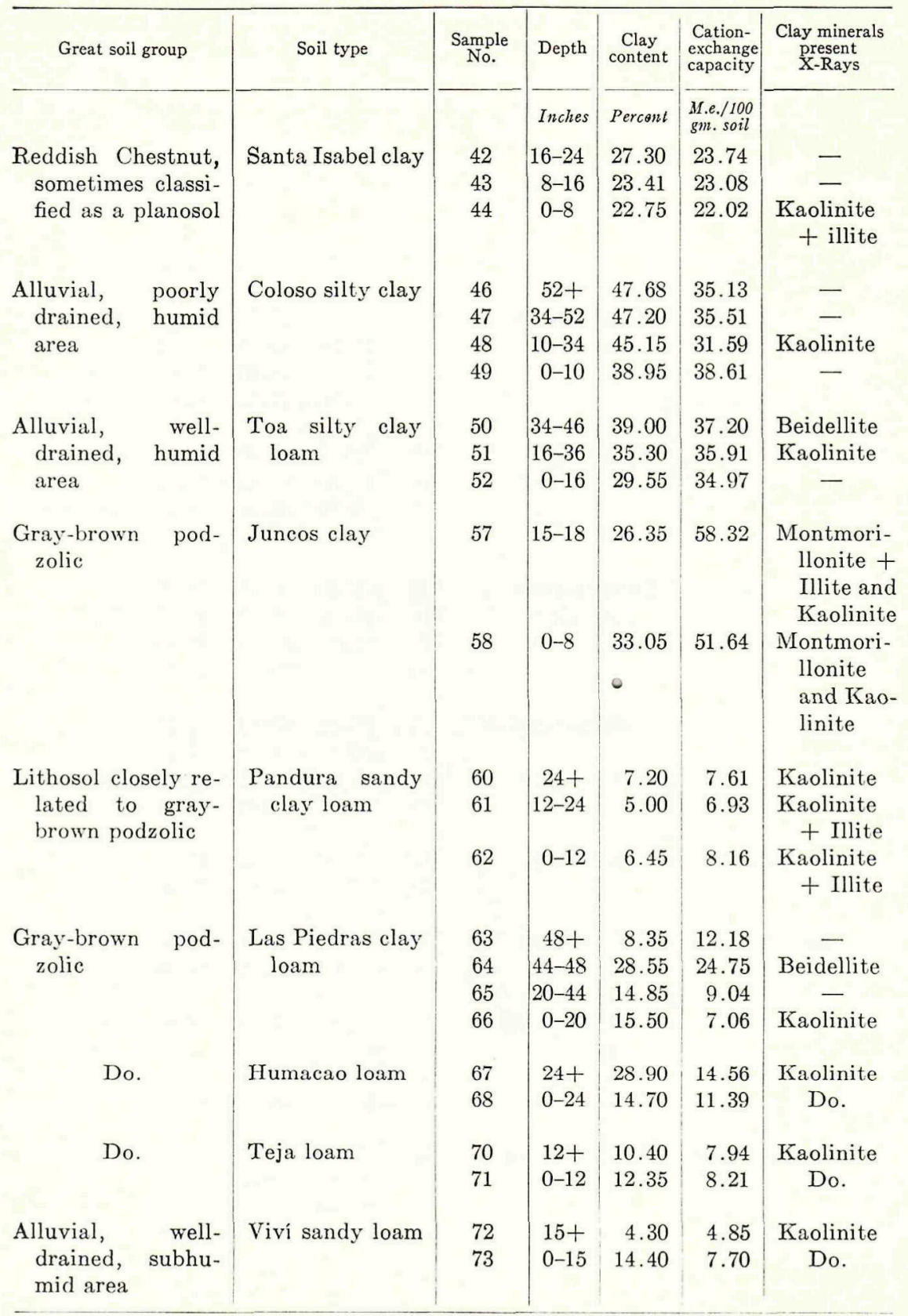


TABLE 9.-Continued

\begin{tabular}{|c|c|c|c|c|c|c|}
\hline Great soil group & Soil type & $\begin{array}{c}\text { Sample } \\
\text { No. }\end{array}$ & Depth & $\begin{array}{c}\text { Clay } \\
\text { content }\end{array}$ & $\begin{array}{c}\text { Cation- } \\
\text { exchange } \\
\text { capacity }\end{array}$ & $\begin{array}{c}\text { Clay minerals } \\
\text { present } \\
\text { X-Rays }\end{array}$ \\
\hline $\begin{array}{l}\text { Reddish-brown } \\
\text { lateric }\end{array}$ & Catalina clay & 81 & $\begin{array}{c}\text { Inches } \\
8\end{array}$ & $\begin{array}{l}\text { Percent } \\
43.95\end{array}$ & $\begin{array}{c}\text { M..e./100 } \\
\text { gnt. soil } \\
10.77\end{array}$ & Kaolinite \\
\hline $\begin{array}{l}\text { Reddish-brown } \\
\text { lateric }\end{array}$ & Cialitos clay & $\begin{array}{l}83 \\
83 \mathrm{~B} \\
84 \\
85 \\
87\end{array}$ & $\begin{array}{c}33-45 \\
9 \\
20-33 \\
10 \\
11\end{array}$ & $\begin{array}{r}48.30 \\
19.05 \\
45.00 \\
42.05 \\
3.90\end{array}$ & $\begin{array}{r}17.83 \\
13.34 \\
14.24 \\
29.10 \\
5.84\end{array}$ & $\begin{array}{l}\text { Kaolinite } \\
\text { Do. } \\
\text { Do. } \\
\text { Do. } \\
\text { Illite }+ \\
\text { Kaolinite }\end{array}$ \\
\hline $\begin{array}{l}\text { Reddish-brown } \\
\text { lateritic }\end{array}$ & Alonso clay & $\begin{array}{l}90 \\
91\end{array}$ & $\begin{array}{l}32+ \\
8 \cdots 18\end{array}$ & $\begin{array}{l}22.00 \\
23.50\end{array}$ & $\begin{array}{l}56.34 \\
43.04\end{array}$ & - \\
\hline $\begin{array}{l}\text { Gray-brown pod- } \\
\text { zolic }\end{array}$ & Ciales clay loam & $\begin{array}{l}92 \\
93\end{array}$ & $\begin{array}{c}7 \\
12\end{array}$ & $\begin{array}{l}9.25 \\
9.15\end{array}$ & $\begin{array}{r}11.80 \\
9.87\end{array}$ & $\begin{array}{l}\text { Kaolinite } \\
\quad+\text { Illite }\end{array}$ \\
\hline $\begin{array}{l}\text { Gray-brown pod- } \\
\text { zolic or Lithosol, } \\
\text { depending on } \\
\text { depth and slope }\end{array}$ & Utuado loam & $\begin{array}{l}95 \\
96 \\
97 \\
98\end{array}$ & $\begin{array}{r}64-72 \\
56-64 \\
24-56 \\
0-24\end{array}$ & $\begin{array}{r}6.45 \\
13.85 \\
19.40 \\
11.35\end{array}$ & $\begin{array}{r}4.27 \\
9.15 \\
10.77 \\
5.22\end{array}$ & $\begin{array}{l}\text { Kaolinite } \\
\text { Do. } \\
\text { Do. } \\
\text { Do. }\end{array}$ \\
\hline Planosol & $\begin{array}{l}\text { Guayabo fine } \\
\text { sand }\end{array}$ & $\begin{array}{l}104 \\
105\end{array}$ & $\begin{array}{c}36+ \\
12-36\end{array}$ & $\begin{array}{r}28.80 \\
5.65\end{array}$ & $\begin{array}{l}7.95 \\
2.20\end{array}$ & $\begin{array}{c}\text { Kaolinite } \\
\text { Do. }\end{array}$ \\
\hline $\begin{array}{l}\text { Red-and-yellow } \\
\text { podzolic }\end{array}$ & Moca clay & 106 & i & 46.60 & 34.11 & $\begin{array}{l}\text { Kaolinite, } \\
\text { Montmo- } \\
\text { rillonite, } \\
\text { Illite }\end{array}$ \\
\hline $\begin{array}{l}\text { Lithosol related to } \\
\text { the Reddish- } \\
\text { brown lateritic }\end{array}$ & $\begin{array}{l}\text { Tanamá stony } \\
\text { clay }\end{array}$ & $\begin{array}{l}108 \\
109\end{array}$ & $\begin{array}{c}2 \\
13\end{array}$ & $\begin{array}{l}51.65 \\
36.70\end{array}$ & $\begin{array}{l}8.46 \\
7.05\end{array}$ & $\begin{array}{c}\text { Kaolinite } \\
\text { Do. }\end{array}$ \\
\hline $\begin{array}{l}\text { Red-and-yellow } \\
\text { podzolic }\end{array}$ & Lares clay & $\begin{array}{l}113 \\
114\end{array}$ & $\begin{array}{l}60+ \\
0-60^{2}\end{array}$ & $\begin{array}{l}44.95 \\
35.25\end{array}$ & $\begin{array}{l}22.60 \\
16.54\end{array}$ & $\begin{array}{c}\text { Kaolinite } \\
\text { Do. }\end{array}$ \\
\hline Rendzina & Soller clay & 117 & $0-18$ & 53.80 & 63.53 & Beidellite \\
\hline $\begin{array}{l}\text { Reddish-brown } \\
\text { lateritic }\end{array}$ & Matanzas clay & 119 & 2 & 60.50 & 7.12 & Kaolinite \\
\hline $\begin{array}{l}\text { Yellowish-brown } \\
\text { lateritic }\end{array}$ & Coto clay & 122 & 2 & 23.00 & 7.70 & Kaolinite \\
\hline
\end{tabular}


TABLE 9.-Concluded

\begin{tabular}{|c|c|c|c|c|c|c|}
\hline Great soil group & Soil type & $\begin{array}{l}\text { Sample } \\
\text { No. }\end{array}$ & Depth & $\begin{array}{c}\text { Clay } \\
\text { content }\end{array}$ & $\begin{array}{l}\text { Cation- } \\
\text { exchange } \\
\text { capacity }\end{array}$ & $\begin{array}{l}\text { Clay minerals } \\
\text { present } \\
\text { X-Rays }\end{array}$ \\
\hline \multirow{5}{*}{$\begin{array}{l}\text { Red-and-yellow } \\
\text { podzolic }\end{array}$} & \multirow{5}{*}{ Cabo Rojo clay } & & Inches & Percent & $\begin{array}{l}\text { M.e./100 } \\
\text { gm. soil }\end{array}$ & \\
\hline & & 132 & $36+$ & 32.80 & 14 & $\begin{array}{l}\text { Kaolinite } \\
+ \text { Mont- } \\
\text { morillo- } \\
\text { nite }\end{array}$ \\
\hline & & 134 & $24-36$ & 34.25 & 11.29 & Beidellite \\
\hline & & 135 & $0-24$ & 26.35 & 14.08 & Do. \\
\hline & & 137 & 15 & 57.23 & 57.58 & \\
\hline \multirow[t]{4}{*}{ Laterite } & \multirow[t]{4}{*}{ Nipe clay } & 156 & 16 & 25.97 & .78 & Kaolinite \\
\hline & & 157 & 17 & 44.37 & .82 & \\
\hline & & 159 & 18 & 9.38 & 19.94 & $\begin{array}{l}\text { Kaolinite } \\
+ \text { ser- } \\
\text { pentine }\end{array}$ \\
\hline & & 160 & $0-24^{19}$ & .87 & .82 & - \\
\hline \multirow{3}{*}{$\begin{array}{l}\text { Reddish-brown } \\
\text { lateritic }\end{array}$} & \multirow{3}{*}{$\begin{array}{l}\text { Bayamón sandy } \\
\text { clay }\end{array}$} & 164 & $18-24$ & 59.70 & 5.47 & Kaolinite \\
\hline & & 165 & $0-18^{2}$ & 25.25 & 5.22 & Do. \\
\hline & & 167 & 20 & 9.00 & 4.08 & Do. \\
\hline $\begin{array}{l}\text { Ground-water pod- } \\
\text { zolic }\end{array}$ & $\begin{array}{l}\text { St. Lucie fine } \\
\text { sand }\end{array}$ & 169 & 21 & 23.50 & 3.48 & Kaolinite \\
\hline $\begin{array}{l}\text { Reddish-brown } \\
\text { lateritic }\end{array}$ & $\begin{array}{l}\text { Catalina stony } \\
\text { clay }\end{array}$ & 172 & 2 & 26.27 & 11.16 & Kaolinite \\
\hline \multirow{6}{*}{$\begin{array}{l}\text { Red-and-yellow } \\
\text { podzolic }\end{array}$} & \multirow[t]{2}{*}{ Los Guineos } & 176 & 22 & 27.90 & 4.52 & Kaolinite \\
\hline & & 182 & 23 & 16.95 & 25.91 & Beidellite \\
\hline & & 183 & 48 & 17.20 & 7.44 & Kaolinite \\
\hline & & 184 & $32-48$ & 17.36 & 7.57 & Do. \\
\hline & & 185 & $24-32$ & 23.15 & 9.18 & Do. \\
\hline & & 186 & $0-24$ & 3.70 & 8.70 & Do. \\
\hline $\begin{array}{l}\text { Reddish-brown } \\
\text { lateritic }\end{array}$ & Río Piedras clay & 190 & 2 & 62.17 & 15.11 & Kaolinite \\
\hline \multirow{2}{*}{$\begin{array}{l}\text { Planosol or ground- } \\
\text { water laterite }\end{array}$} & \multirow{2}{*}{$\begin{array}{l}\text { Sabana-Seca } \\
\text { sandy clay }\end{array}$} & 193 & 24 & 3.83 & .47 & Kaolinite \\
\hline & & 194 & $0-12^{2}$ & 21.50 & 7.11 & \\
\hline $\begin{array}{l}{ }^{1} \text { B Horizon. } \\
{ }^{2} \text { Surface. } \\
{ }^{3} \text { C Horizon. } \\
{ }^{4} \text { Yellow decomposed rock. } \\
{ }^{5} \text { Below. } \\
{ }^{6} \text { Hard-layer pebbles. } \\
{ }^{7} \text { Subsoil. } \\
{ }^{8} \text { Soil directly from rock. } \\
{ }^{9} \text { Rock. }\end{array}$ & \multicolumn{3}{|c|}{$\begin{array}{l}{ }^{10} \text { Ashlike material. } \\
11 \text { Weathered sandstone. } \\
{ }^{12} \text { Disintegrated rock. } \\
{ }^{13} \text { Soft limestone. } \\
{ }^{14} \text { Sample lost. } \\
{ }^{15} \text { Green clay. } \\
16 \text { Below concretions. } \\
{ }^{17} \text { Above concretions. } \\
{ }^{18} \text { Residue. }\end{array}$} & \multicolumn{3}{|c|}{$\begin{array}{l}{ }^{19} \text { Soil. } \\
{ }^{20} \text { Sandy soil. } \\
{ }^{21} \text { Clay layer. } \\
{ }^{22} \text { Decomposed rock. } \\
{ }^{23} \text { Decomposed parent ma- } \\
\text { terial. } \\
{ }^{24} \text { Organic-sandy layer. }\end{array}$} \\
\hline
\end{tabular}


had on the average a lower clay content than those containing none, or minute traces only. Table 8 shows these average figures for soils of the upland, inner plains, and terrace and alluvial fan groups.

The clay content, cation-exchange capacity, and clay minerals present in 38 soils series studied, comprising 99 samples at various depths, are reported in table 9. The clay minerals identified consisted of kaolinite, illite, montmorillonite, chlorite, and a mineral identified tentatively as beidellite. The soil samples wherein kaolinite was identified had the lowest mean clay content and cation-exchange capacity (table 10) and those in which montmorillonite was found had the highest. The mean cationexchange capacity for soils containing beidellite and montmorillonite were approximately three and five times higher, respectively, than those containing kaolinite.

TABLE 10.-Mean clay content, cation-exchange capacity, and clay-mineral content of soil samples studied

\begin{tabular}{c|c|c|l}
\hline \multirow{2}{*}{ Number of samples } & Clay content & $\begin{array}{c}\text { Cation exchange } \\
\text { capacity }\end{array}$ & \multicolumn{1}{|c}{ Mineral } \\
\cline { 2 - 3 } 42 & Percent & M.e./100 gm. soil & \\
1 & 26.57 & 10.07 & Kaolinite \\
20 & 26.60 & 22.30 & Illite \\
3 & 29.96 & 31.41 & Beidellite \\
\cline { 2 - 3 } & -35.30 & 48.00 & Montmorillonite \\
\hline
\end{tabular}

In the upland soils containing feldspar, kaolin was the predominating clay mineral with one exception (Descalabrado) where illite predominated. With the kaolin were varying quantities of montmorillonite, illite, and the beidellite mineral. Where no feldspar occurred kaolin was predominant with small quantities of illite.

The inner plains soils contained beidellite predominantly, apparently being formed from kaolin and, in addition, small quantities of illite and montmorillonite occurred.

In the terrace and alluvial fans. kaolin was generally found with beidellite and illite.

In the coastal-plains soils where no feldspar was observed kaolin predominated, and in the river flood-plains soils, all of which contained feldspar, beidellite was the chief clay mineral with traces of illite and chlorite.

It was interesting to note that in many instances the beidellitelike mineral was formed in the lower horizons of soils in which the feldspar content of the very fine sand and silt fractions increased with depth. This can be seen in table 5 for Las Piedras, San Antón, and Toa. Where feldspar decreased with depth, kaolin appeared to predominate throughout the profile. Where 
illite and chlorite occurred in the upper horizons, weathering reactions appeared to change these clay minerals to beidellite. In the San Antón soil, illite, kaolin, and chlorite occur in the 0-24-inch horizon, chlorite does not occur in the 24-29-inch horizon, illite and kaolin persist to a depth of 44 inches, and beidellite occurs at 44 inches + . Apparently under the extreme weathering conditions in the Tropics, chlorite and illite are not very resistant.

In the course of this study some interesting observations were made which appear to lead to some valuable information. From the standpoint of the presence and absence of feldspars which has been noted previously herein, comparisons of the productivity ratings of these soils as reported in the Soil Survey Report (13) show that those containing feldspar have a productivity rating almost three times as high as those containing none, except where lack of rainfall and excessive erosion are factors.

Another comparison was based on the presence of available potassium. In a study using Hegari sorghum as a plant index (5) Capó determined the relative availability of nitrogen, phosphorus, and potassium in 56 soils of Puerto Rico. Included in that study were 25 of the soil series reported here. Fourteen of these soils contained feldspar in the very fine sand and silt fractions, and 11 did not. The average relative available potassium of these two groups showed that the soils containing feldspar also contained 2.2 times as much available potassium as those in which no feldspar occurred. Since the feldspars in these soils are plagioclase and should contain no potassium, and also since muscovite, another common potash mineral does not occur, the source of this available potash is of interest. As shown in table 8, the average clay content of the soils containing feldspar is lower than that of those which do not.

The evidence suggests that the feldspar minerals might constitute a source of potash. Winchell (15) stated that, under certain conditions, the albite molecule forms three crystal phases with sanidine, adularia, and microcline, all of which are potash feldspars of the general formula $\mathrm{K}_{2} \mathrm{O}$ $\mathrm{Al}_{2} \mathrm{O}_{3} \cdot 6 \mathrm{SiO}_{2}$. In general, calling the potash feldspar orthoclase for comparative purposes, and using the abbreviations Or for orthoclase and $\mathrm{Ab}$ for albite, Winchell mentioned three possible series, vis, $\mathrm{Or}_{50} \mathrm{Ab}_{50}$ to about $\mathrm{Or}_{10} \mathrm{Ab} \mathrm{b}_{90}, \mathrm{Or}_{80} \mathrm{Ab} \mathrm{b}_{20}$ to about $\mathrm{Or}_{40} \mathrm{Ab}_{60}$ and $\mathrm{Or}_{40} \mathrm{Ab}_{60}$ to $\mathrm{Or}_{10} \mathrm{Ab} \mathrm{b}_{90}$.

\section{SUMMARY}

The constituent minerals in the very fine sand, silt, and clay fractions of some of the important soils of Puerto Rico were studied using petrographic and X-ray methods.

It was found that these soils could be divided into two general groups: Those that contained appreciable feldspar and those in which feldspars 
were totally absent or occurred in minute traces. Study of the profile characteristics showed that the feldspar content of the profile allowed a further subdivision into: Those in which the feldspar decreased with depth; and those in which feldspar increased with depth. The feldspars identified consisted almost exclusively of plagioclase, albite, oligoclase, and andesine, these being the principal constituents, with traces of labradorite and very small traces of orthoclase.

The clay minerals identified in the soil studied consist of either kaolin, hydrous mica, or illite, one tentatively identified as beidellite, and montmorillonite, with mean cation-exchange capacities of 10.07, 22.30, 31.41, and 48.00 milliequivalents per $100 \mathrm{gm}$. of soil, respectively. Some soils contained a combination of two or three of these clay minerals. In the upland soils where feldspar occurred, kaolin was the predominating mineral with varying quantities of hydrous mica and montmorillonite. Where no feldspar occurred in the upland soils, the clay mineral was principally kaolin. The inner-plains soils chiefly contained beidellite, regardless of whether feldspar was present or not. Five soils of the terraces and alluvial fans contained feldspar and one did not, and kaolin was the principal clay mineral. The river flood-plain soils all contained feldspar and beidellite was the predominant clay mineral. The coastal-plain soils contained no feldspar and kaolin predominated.

The occurrence of the feldspar in a profile seems to have some bearing on the clay minerals formed by the weathering processes. Where feldspars increased with depth, beidellite seemed to be the ultimate clay mineral formed. Where feldspar decreased, the clay mineral formed was kaolin.

By comparing the presence or absence of feldspar with the productivity rating as determined by the Soil Survey of Puerto Rico, it was found that soils containing feldspar had a much higher productivity rating than those from which it was absent, or in which it occurred only in small traces - also that soils containing feldspar had a lower clay content than those which did not.

If the available potash content using Hegari sorghum was regarded as a plant index, comparisons showed that soils containing feldspar also contained about 2.2 times more available potash than those lacking feldspar.

In general, the results obtained indicate that the most productive soils studied were those that contained fairly large quantities of feldspar, had a low clay content, and the clay minerals of which were mixtures of kaolin, hydrous mica, and beidellite and, in some cases, montmorillonite.

\section{RESUMEN}

Los minerales constituyentes de todos los suelos son: el cuarzo, los feldespatos, las micas y los del grupo de la arcilla. Para identificar estos 
minerales en los suelos de Puerto Rico que se estudiaron, se trataron las muestras, químicamente, con el objeto de eliminar la materia orgánica y los sesquióxidos de aluminio y de hierro. Los residuos limpios se separaron, mediante el análisis mecánico, en fracciones de arena muy fina, limo y arcilla. Se identificaron los minerales, constituyentes de cada una de estas fracciones, por medio de los métodos petrográficos y de los rayos X.

El cuarzo se encontró en las tres fracciones estudiadas, pero las micas y, especialmente, la mica muscovita que, generalmente, abunda en los suelos, no apareció.

Estos suelos estudiados pueden dividirse en dos grupos amplios; aquéllos que contienen suficiente cantidad de feldespatos y los que contienen indicios o ningún feldespato.

El estudio del perfil señaló también aquellos suelos en que los feldespatos disminuían, a medida que aumentaba su profundidad, y aquéllos donde los feldespatos aumentaban. Los feldespatos principales, identificados, consistían, principalmente, de los grupos plagioclasa, oligoclasa y andesina, con indicios de labradorita e indicios ínfimos de ortoclasa.

Los minerales identificados en el grupo de la arcilla, consistían de caolina, o de mica hidratada, ilita, o montmorillonita, con valores promedios, de intercambio de bases, de 10.07, 22.30, 31.41, y 48.00 miliequivalentes por 100 gramos de suelo, respectivamente.

También se identificó un grupo, tentativamente, como beidelita. Algunos suelos contenían una combinación de dos o tres minerales del grupo de la arcilla.

En los suelos de la altura de Puerto Rico que contenían feldespatos, el mineral predominante era la caolina, con cantidades variables de mica hidratada y montmorillonita. En aquéllos, donde no había feldespatos, el mineral predominante era la caolina, principalmente.

Los suelos del interior contenían beidelita, principalmente, con o sin feldespatos. Cinco suelos del grupo de las terrazas y abanicos de aluvión contenían feldespatos. Sin embargo, el otro suelo del grupo no lo tenía, pero en todos, el mineral predominante era la caolina.

Todos los suelos de las llanuras, sujetos a inundación, contenían feldespatos y beidelita.

Los suelos de las llanuras costaneras no contenían feldespatos, pero la caolina predominaba.

La presencia de los feldespatos en el perfil, señalaba una relación entre los minerales del grupo de la arcilla y el proceso de meteorización. Cuando los feldespatos aumentaban, según la profundidad, la beidelita predominaba, y cuando los primeros disminuían, la caolina predominaba.

En los suelos más fértiles, los feldespatos predominaban y el contenido de arcilla era menor que en los menos fértiles. 
Tomando como base el contenido de potasa asimilable, determinado cuando se usó la planta sorgo Hegari, como índice, se encontró que los suelos que contenían feldespatos tenían alrededor de 2.2 veces más potasa asimilable que los que no los contenían.

Los resultados indican que los suelos más productivos fueron aquéllos con mayor cantidad de feldespatos y menor de arcilla. Los minerales de estos suelos más productivos, en el grupo de la arcilla, consistían de mezclas de caolina, mica hidratada, y en algunos casos de montmorillonita.

\section{LITERATURE CITED}

1. Bonnet, J. A., Soil mineralogy; Annual Report of the Director, Institute of Tropical Agriculture of P. R., 1943-44, pp. 104-5.

2. Bonnet, J. A., Mineralogical characteristics and mode of formation of tropical soils, Annual Report of the Director, Institute of Tropical Agriculture of P. R., 1944-45, pp. 58-9.

3. Bonnet, J. A., The nature of laterization as revealed by chemical, physical, and mineralogical studies of a lateritic soil profile from Puerto Rico, Soil Sci. 48 25-40 1939.

4. Bonnet, J. A., Broad classification of tropical soils in Puerto Rico by various practical systems, Proceedings of the First Commonwealth Conference of Tropical and Subtropical Soils, 1948, pp. 103-6, Commonwealth, Bureau of Soil Science, Tech. Communication 46, Harpenden, England, 1949.

5. Capó, B. G., Cantidades asimilables de nutrimentos en los suelos de Puerto Rico (Available nutrients in the soils of Puerto Rico), Informe Bienal, 19381940, Estación Foxperimental Agrícola (Biannual Report, 1938-1940, Agricultural Experiment Station), Río Piedras, P. R., pp. 59-61.

6. Jeffries, C. D., A method of preparing soils for petrographic analysis, Soil Sci. $52,451-41941$.

7. Jeffries, C. D., A rapid method for the removal of free iron oxides in soil prior to petrographic analysis, Soil Sc. Soc. of Amer. Proc. 11 211-2 1946.

8. Jeffries, C. D., The use of the X-ray spectrometer in the determination of the essential minerals in soils, Soil Sci. Soc. of Amer. Proc. 12 135-40 1947.

9. Jeffries, C. D., The mineralogical approach to some soil problems, Soil Sci. 63 315-20 1947.

10. Jeffries, C. D. and Jackson, M. L., Mineralogical analysis of soils, Soil Sci. 68 57-73 1949.

11. Jeffries, C. D., Bonnet, J. A., and Abruña, F., Mineral characteristics of some soils of Puerto Rico, Soil Sci. Soc. of Amer. Proc. 16(3) 310-11 July 1952.

12. Marshall, C. E. and Jeffries, C. D., Mineralogical methods in soil research, Soil Sci. Soc. of Amer. Proc. 10 397-405 1945.

13. Roberts, R. C. and party, Soil Survey Puerto Rico, U. S. Department of Agriculture, Bur. of Plant Ind., in coop. with the Univ. of P. R. Agr. Expt. Sta., Series 1936, No. 8, 503 pp., 1942.

14. Thorp, James, Some important soil profiles of southern Puerto Rico, Soil Sci. 34 241-57 1932.

15. Winchell, A. N., Elements of optical mineralogy, An introduction to microscopic petrography: Part II, Description of minerals, p. 298, 4th edition, 551 pp., John Wiley \& Sons, Inc., New York, N. Y., 1951. 